\title{
Serum Sickness, CTCAE 5.0
}

National Cancer Institute

\section{Source}

National Cancer Institute. Serum Sickness, CT CAE 5.0. NCI Thesaurus. Code C146642.

A disorder characterized by a delayed-type hypersensitivity reaction to foreign proteins derived from an animal serum. It occurs approximately six to twenty-one days following the administration of the foreign antigen. Symptoms include fever, arthralgias, myalgias, skin eruptions, lymphadenopathy, chest marked discomfort and dyspnea. 